\title{
Determination of anticholinesterase and antioxidant activities of methanol and water extracts of leaves and fruits of Chamaerops humilis L.
}

\section{Aicha Bouhafsoun*}

Laboratoire de Production et valorisation végétale et microbienne, Département de Biotechnologie, Faculté SNV, Université des Sciences et Technologie Mohamed Boudiaf (USTOMB), Bp 1505 El M'naouer Oran 31000, Algérie

\section{Mehmet Boga}

Department of Pharmaceutical Technology, Faculty of Pharmacy, Dicle University, Diyarbakir, 21280, Turkey

\section{Ahmed Boukeloua}

Département des sciences de la nature et de la vie, Faculté des sciences exactes et sciences de la nature et de la vie, Université Larbi ben M'Hidi Oum-EL-Bouaghi, Oum-EL -Bouaghi, Algérie

Hamdi Temel

Department of Pharmaceutical Chemistry, Faculty of Pharmacy, Dicle University, Diyarbakir, 21280, Turkey

Meriem Kaid-Harche

Laboratoire de Production et valorisation végétale et microbienne, Département de Biotechnologie, Faculté SNV, Université des Sciences et Technologie Mohamed Boudiaf (USTOMB), Bp 1505 El M'naouer Oran 31000, Algérie

*Corresponding author. E-mail: abouhafsoun@gmail.com

\section{Abstract}

The present study was carried out to investigate the antioxidant activity of the water and methanol extracts of leaves and fruits extracts of Chamaerops humilis L. by using ABTS cation radicals and cupric reducing antioxidant capacity (CUPRAC). Anticholinesterase effect of the extracts was tested against both AChE and BChE using a microplate-reader assay based on the Ellman method. The methanol extracts of $C$. humilis leaves contained relatively higher content of flavonoids and total phenolics than those of fruits. All the extracts were found to have different levels of antioxidant activity in the systems tested. The leave extract showed the highest value of antioxidant activity, based on ABTS radicalscavenging activity, while the fruit water extract showed the highest value $(0.53 \pm 0.50 \mu \mathrm{g} /$ $\mathrm{mL}$ ) of cupric reducing antioxidant activity. Our data indicates that both methanol and water fruit extract were active for BChE inhibition $(31.65 \pm 0.37$ and $30.19 \pm 0.56 \%)$ respectively, whereas, all leave extracts did not show any activity against BChE. The present study demonstrated that the methanol and water extracts fractions of $C$. humilis have different responses with different antioxidant methods. Our results suggest that the $C$. humilis could be used as a source of antioxidant agents and may be beneficial in the $A D$ treatment.

Keywords: Biological activity, Chamaerops humilis L., Methanol extract, Secondary metabolites, Water extract

\section{INTRODUCTION}

Algeria has a rich flora, and researchers have wide knowledge of their native medicinal plants. Medicinal plants represent an important constituent of flora and are broadly distributed in several regions of Algeria.

Chamaerops humilis L., var. argentea, is an Arecaceae widely distributed in all Mediterranean countries particularly in Algeria which has been located especially in coastal, arid and semi-arid regions. In addition, its also present in other plac-

\section{Article Info}

DOI:10.31018/

jans.v11i1.2001

Received: January 26, 2019

Revised: February 17, 2019

Accepted: February 20, 2019

\section{How to Cite}

Bouhafsoun, A. et al. (2019). Determination of anticholinesterase and antioxidant activities of methanol and water extracts of leaves and fruits of Chamaerops humilis L.. Journal of Applied and Natural Science, 11(1): 144-148

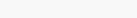


messaoud et al., 2014, Gonçalves et al., 2018) hypolipidemic and hypoglycemic (Gaamoussi et al., 2010), antilithic (Beghalia et al., 2008) urinary antiseptic and anti-inflammatory (Bellakhdar et al.,1991) and anticholinesterase (Gonçalves et al., 2018) activities. Besides its medicinal importance, Chamaerops presents an ecologically important role, it provides protection against erosion (Khoudali et al., 2014) since it allows attachment of the soil and fight against desertification.

Previous studies have shown that C.humilis contained phenolic compounds, including flavonoids, tannins, saponins, coumarines, quinons (Benahmed-Bouhafsoun et al., 2013) sterols and terpenoids (Hasnaoui et al., 2013). Herein, the anticholinesterase and antioxidant activities, and total phenolic and flavonoid contents of leaves and fruits methanol extracts of $C$. humilis $\mathrm{L}$. were investigated in detail.

\section{MATERIALS AND METHODS}

The plant material (Chamaerops humilis L.) was collected from western Algeria (Oran).

Preparation of the extracts: Three $\mathrm{g}$ of dried samples were soaked in $50 \mathrm{~mL}$ of $80 \%$ aqueous methanol and ultrapure water at $60^{\circ} \mathrm{C}$ for $30 \mathrm{mn}$ under continuous reflux. The extracts were filtered through nylon mesh. The extraction was repeated two times. The filtrates obtained were dried using a rotary evaporator at $30^{\circ} \mathrm{C}$.

Instruments and Chemicals: A microplate reader (BioTek Power Wave XS, USA) and UV spectrophotometer were used for the antioxidant and anti-Alzheimer activities assays. All the chemicals using in antioxidant and anti-Alzheimer activities were analytical grade and purchased from Merck (Germany), Sigma (Germany), Aldrich (Germany), Sigma-Aldrich (Germany), Applichem (Germany), Fluka (Germany).

Determination of total phenolic and flavonoid content: The concentrations of phenolic content in the crude extracts were expressed as micrograms of pyrocatechol equivalents (PEs) (Slinkard and Singleton, 1977). Eight microlitre of the extract in methanol was added to $176 \mu \mathrm{L}$ of distilled $\mathrm{H}_{2} \mathrm{O}$ and $4 \mu \mathrm{L}$ of Folin-Ciocalteu's Reagent, and mixed. After $3 \mathrm{~min}, 12 \mu \mathrm{L}$ of $\mathrm{Na}_{2} \mathrm{CO} 3$ $(2 \%)$ was added, and the mixture was shaken for $2 \mathrm{~h}$ at room temperature. The absorbance was measured at $760 \mathrm{~nm}$. Total phenolic content was calculated according to the following equation.

Absorbance $=0.0296$ pyrocatechol $(\mu \mathrm{g})+0.0177$ $\left(R^{2}=0.9952\right) \quad$............ 1

Total flavonoid content of the extracts was measured according to the method described by Moreno et al. and results were expressed as quercetin equivalents (Moreno et al., 2000).Twenty microliter of the solution (1 $\mathrm{mg}$ of extract in methanol) was added to $4 \mu \mathrm{L}$ of $10 \%$ aluminium nitrate, $4 \mu \mathrm{L}$ of $1 \mathrm{M}$ potassium acetate and $172 \mu \mathrm{L}$ of methanol.
After forty minutes, the absorbance was measured at $415 \mathrm{~nm}$. Total flavonoid content was calculated according to the following equation:

Absorbance $=0.2956$ quercetin $(\mu \mathrm{g})-0.1394$ $\left(R^{2}=0.9922\right) \quad \ldots \ldots \ldots .$. Eq. 2

Antioxidant activity of the extracts: ABTS cation radical scavenging activities ( $\mathrm{Re}$ et al., 1999), and cupric reducing antioxidant capacity (CUPRAC) (Apak et al., 2004) methods were used to determine antioxidant activities of the extracts.

ABTScation radical decolorization assay: 7 $\mathrm{mM}$ ABTS in distilled water was added to $2.45 \mathrm{mM}$ potassium persulfate to produce ABTS • and solution was kept in the dark at room temperature for 12-16 h. The solution was diluted with ethanol until an absorbance of $0.700 \pm 0.025$ at $734 \mathrm{~nm}$ was obtained. $40 \mu \mathrm{L}$ of each sample solution at different concentrations was added to $160 \mu \mathrm{L}$ of ABTS • solution. After $30 \mathrm{~min}$, the percentage inhibition was measured $734 \mathrm{~nm}$. The scavenging capability of $\mathrm{ABTS}^{+15}$ was calculated according to the following equation:

$\mathrm{ABTS}^{*+}$ scavenging effect (Inhibition \%) =

$$
\frac{A_{\text {control }}-A_{\text {sample }}}{A_{\text {control }}} \times 100 \quad \text {....Eq.3 }
$$

Cupric reducing antioxidant capacity (CUPRAC) method: Aliquots of $61 \mu \mathrm{L}$ of $\mathrm{CuCl}_{2}$ $(1.0 \times 10-2 \mathrm{M}), 61 \mu \mathrm{L}$ of neocuproine $(7.5 \times 10-3$ $\mathrm{M})$ and $61 \mu \mathrm{L}$ of $\mathrm{NH}_{4} \mathrm{OAc}$ buffer (1 M, pH 7.0) solution were stirred, $x \mu \mathrm{L}$ sample solution $(2.5,6.25$, 12.5, and $25 \mu \mathrm{L})$ and $(67-\mathrm{x}) \mu \mathrm{L}$ distilled $\mathrm{H}_{2} \mathrm{O}$ were added until the final volume $250 \mu \mathrm{L}$ was attained. The tubes were left to standing for $1 \mathrm{~h}$. The absorbance was measured at $450 \mathrm{~nm}$ against a blank reagent (Apak et al., 2004).

Anticholinesterase activity of the extracts: The acetyl-cholinesterase and butyryl-cholinesterase inhibitory activities of the extracts were tested by using the method developed by Ellman et al. (1961).

Ten microliter of sample solution and $20 \mu \mathrm{L} B C h E$ (or AChE) were added to $150 \mu \mathrm{L}$ of $100 \mathrm{mM}$ sodium phosphate buffer ( $\mathrm{pH}$ 8.0). Solution were stirred and incubated at room temperature for 15 min, then $10 \mu \mathrm{L}$ of DTNB was added to mixture. The reaction was started by the addition of $10 \mu \mathrm{L}$ butyrylthiocholine iodide (or acetylthiocholine iodide). Microplate reader (BioTek Power Wave XS) at $412 \mathrm{~nm}$ was used to monitor the hydrolysis of these substrates.

$$
\text { Inhibition } \%=\frac{A_{\text {control }}-A_{\text {sample }}}{A_{\text {control }}} \times 100
$$

For antioxidant tests the final concentrations of each method are 10, 25, 50 and $100 \mu \mathrm{g} / \mathrm{mL}$. For anticholinesterase activity, final concentration 
is $200 \mu \mathrm{g} / \mathrm{mL}$.

Statistical Analysis: All measurements were carried out in triplicate and results were expressed as mean \pm standard deviation (SD). The statistical significance was evaluated using a Student's $t$ test, $p$ values $<0.05$ were considered as significant.

\section{RESULTS AND DISCUSSION}

Content of phenolic compound and flavonoids: Results from evaluation of total flavonoid and total phenolic contents of methanolic and water extracts prepared from leaves and fruits were determined as quercetin and pyrocatechol equivalents, respectively and are shown in Table 1. The total phenolic content was detected to be higher in water extract of $C$. humilis leave with $72.3 \pm 0.97$ $\mu \mathrm{gPEs} / \mathrm{mg}$ of extract and was considerably decreased in methanol extract $62.16 \pm 1.15$ $\mu \mathrm{gPEs} / \mathrm{mg}$ of extract of the same sample. Furthermore, the fruit of both methanol and water extracts showed similarity of phenolic content, 57.09 $\pm 1.41 \mu \mathrm{gPEs} / \mathrm{mg}$ and 58.78 $\pm 1.19 \mu \mathrm{gPEs} / \mathrm{mg}$ respectively, these values were found to be lower than the leave samples.

The results of quantitative analysis of flavonoid (Table 1) indicated that a higher content of flavonoids was obtained in the methanol extract of $C$. humilis leave with $7.69 \pm 0.17 \mu \mathrm{g}$ in terms of quercetin equivalents/mg of extracts, followed by water extract $6.95 \pm 0.22 \mu \mathrm{gQEs} / \mathrm{mg}$ extract. However, in fruit both methanol and water extracts registered much lower amounts of flavonoids with $6.18 \pm 0.05 \mu \mathrm{g} / \mathrm{mg}$ and $6.57 \pm 0.33 \mu \mathrm{g} / \mathrm{mg}$, respectively. This difference was less pronounced. In pre- vious studies, the presence of phenolic substances including flavonoids was reported $(3.70 \mathrm{mg} / \mathrm{g})$ in $C$. humilis L. (Khoudali et al., 2014).

Furthermore, flavones C-glycosides and tricin were identified in C. humilis leaves (Williams and Harborn, 1973). Rutin, apigenin and luteolin were also revealed in leaves and fruits extracts of Chamaerops humilis L. (Bouhafsoun et al., 2018).

The results of this study highly imply that phenolic components are important components in Chamaerops and some of its biological properties could be attributed to the presence of these constituents. The reason for the observed variance in content of phenolics may be due to the variation in accumulation of these substances in several tissues and cells as epidermal cells of leaves, vaxes and external surfaces of fruits (Hutzler et al., 1998; Kuppusamy et al., 2016).

Antioxidant properties of different extracts: In the current study, the antioxidant activity of $C$. humilis extracts were determined in view of the CUPRAC and ABTS+ radical scavenging capacity of fruit and leave methanol and water extracts. The obtained results as can be seen in Figure 1 and Table 2 indicate that the highest ABTS scavenging activity was demonstrated by methanol leave extracts $(50.11 \%$ in ABTS assay), which was richer in flavonoid contents. This activity was two times higher than in methanol fruit extracts, whereas the other remaining water extracts had comparatively low activity (20.35\%).

Comparison between solvent extraction showed that the Methanol extracts have good activity against ABTS compared to the water solvent extracts (Figure 1).

Table 1. Total phenolic and flavonoid contents and anticholinesterase activity of Chamaerops extracts ${ }^{\mathrm{a}}$.

\begin{tabular}{lllll}
\hline Extracts & $\begin{array}{l}\text { Phenolic content } \\
(\boldsymbol{\mu g} \text { PEs/mg extract })^{\mathbf{b}}\end{array}$ & $\begin{array}{l}\text { Flavonoid content } \\
(\boldsymbol{\mu g} \text { QEs/mg extract })^{c}\end{array}$ & $\begin{array}{l}\text { Inhibition \% } \\
\text { Against AChE }\end{array}$ & $\begin{array}{l}\text { Inhibition \% } \\
\text { Against BChE }\end{array}$ \\
\hline Fruit Methanol & $58.78 \pm 1.19$ & $6.18 \pm 0.05$ & $\mathrm{NA}$ & $31.65 \pm 0.37$ \\
Fruit Water & $57.09 \pm 1.41$ & $6.57 \pm 0.33$ & $\mathrm{NA}$ & $30.19 \pm 0.56$ \\
Leave Methanol & $62.16 \pm 1.15$ & $7.69 \pm 0.17$ & $\mathrm{NA}$ & $\mathrm{NA}$ \\
Leave Water & $72.30 \pm 0.97$ & $6.95 \pm 0.22$ & $\mathrm{NA}$ & $\mathrm{NA}$ \\
Galanthamine $^{\mathrm{d}}$ & - & - & $86.25 \pm 0.31$ & $77.41 \pm 0.16$
\end{tabular}

${ }^{\mathrm{a}}$ Values are means \pm S.D. of three parallel measurements, $p<0.05$, significantly different with Student's $t$-test. ${ }^{\mathrm{b}}$ PEs, pyrocatechol equivalents; ${ }^{c}$ QEs, quercetin equivalents; ' Standard drug; NA: Not active

Table 2. Cupric reducing antioxidant capacity of $C$. humilis extracts.

\begin{tabular}{lclll}
\hline Extracts & $\mathbf{1 0} \mathbf{\mu g} / \mathbf{m L}$ & $\mathbf{2 5} \mathbf{\mu g} / \mathbf{m L}$ & $\mathbf{5 0} \mathbf{~ g} / \mathbf{m L}$ & $\mathbf{1 0 0} \mathbf{\mu g} / \mathbf{m L}$ \\
\hline Fruit Methanol & $0.139 \pm 0.011$ & $0.145 \pm 0.028$ & $0.183 \pm 0.014$ & $0.243 \pm 0.009$ \\
Fruit Water & $0.088 \pm 0.008$ & $0.109 \pm 0.007$ & $0.203 \pm 0.097$ & $0.531 \pm 0.500$ \\
Leave Methanol & $0.128 \pm 0.025$ & $0.169 \pm 0.004$ & $0.265 \pm 0.025$ & $0.395 \pm 0.002$ \\
Leave Water & $0.091 \pm 0.009$ & $0.121 \pm 0.006$ & $0.164 \pm 0.016$ & $0.301 \pm 0.034$ \\
BHT & $1.456 \pm 0.101$ & $2.723 \pm 0.304$ & $3.820 \pm 0.084$ & $3.940 \pm 0.142$ \\
TOC & $0.454 \pm 0.026$ & $1.179 \pm 0.093$ & $1.965 \pm 0.181$ & $3.260 \pm 0.015$ \\
\hline
\end{tabular}

Values expressed are means \pm S.D. of three parallel measurements and values given as absorbance 


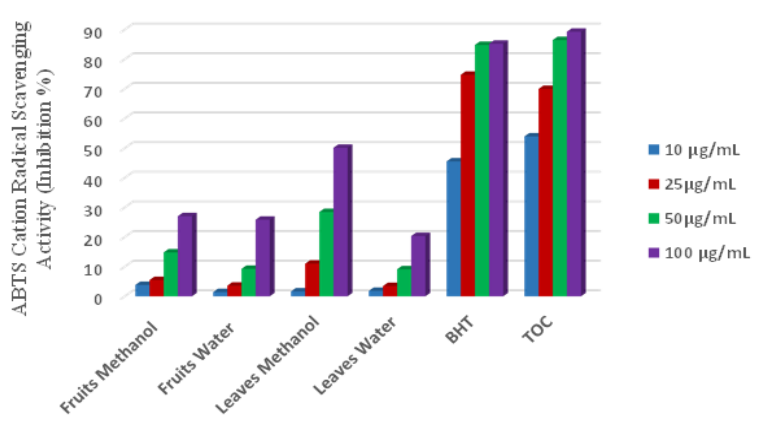

Fig. 1. ABTS cation radical scavenging activity of $C$. humilis L. extracts, $\alpha-T O C$ and BHT. Values are means \pm S.D., $n=3$. $p<0.05$, significantly different with Student's t-test.

Againts CUPRAC, the results showed that the cupric ions $\left(\mathrm{Cu}^{2+}\right)$ reducing capacity of the water extract of $C$. humilis fruit was twice higher than the methanol extract tested $(0.531$ and 0.243$)$ respectively, but lower than synthetic antioxidants $\alpha$ tocopherol ( $\alpha$-TOC) and butylated hydroxytoluene (BHT) (Table 2). Although, the all the leave extracts exhibited moderate activity in CUPRAC method at four different concentrations.

The results of this study were compared with those obtained by previous research, which determined the antioxidant properties of $C$. humilis leaves by the DPPH method. They reported an $\mathrm{IC}_{50}$ of $180.71 \pm 6.6 \mu \mathrm{g} \mathrm{mL}^{-1}$ in a DPPH assay (Benahmed-Bouhafsoun et al., 2013). The total antioxidant activity of several Arecaceae was evaluated based on scavenging activity of DPPH free radicals, among them the date fruits of Phœnix dactylifera of Oman showed an inhibition value about $65 \%$ (Singh et al., 2012), and $67 \%$ in the leaf extract of Hyphaene thebaica (Mohamed et al., 2009).

In general, $C$. humilis leaves have a better antioxidant profile. The result was related with their flavonoids and phenolic content.

Anticholinesterase activity: The deficit of acetylcholine in the brain could be causes the Alzheimer's disease (AD) which is the most common form of neurodegenerative disease (Bachman et al., 1992). Therefore, AD can be treated with both two form of cholinesterase, acetylcholinesterase (AChE) and butrylcholinesterase (BChE) (Jaen et al., 1996). This study evaluated the anticholinesterase activity of $C$. humilis using the Ellman method, Galantamine was used as positive control which is used for Alzheimer's disease. The results obtained from this study showed that all the Chamaerops fruit extracts exhibited moderate inhibition against butyrylcholinesterase enzyme (BChE) at $200 \mu \mathrm{g} / \mathrm{mL}$ concentration. As shown in Table 1, it showed $31.65 \%$ for the methanol and $30.19 \%$ for the water extract inhibitory activity against BChE. Some studies have reported the anti-cholinesterase activity due to the presence of active compounds including flavonoids, tannins, alkaloids, quinins, stilbens and xanthons (Pinho et al., 2013, Silva et al., 2014; Gonçalves et al., 2018).

Contrariwise, no extracts from the leave have shown any inhibition against acetyl and butyrylcholinesterase enzyme. Also, the methanol and water fruit extracts displayed no activity on acetylcholinesterase at $200 \mu \mathrm{g} / \mathrm{mL}$.

\section{Conclusion}

In this study, extracts of Chamaerops humilis L., demonstrated that they not only possesses antioxidant and radical scavenging activities but also exhibit inhibitory potential against acetylcholinesterase. Furthermore, the fruit extracts exhibited promising anticholinesterase activity, constituting the first report of anticholinesterase activity to extracts from Algerian C. humilis. Consequently, leave and fruit $C$. humilis that are rich in phenolics and flavonoids and promising for the development of safe food products and can be used for the future therapeutic medicine.

\section{ACKNOWLEDGEMENTS}

This work is supported by High Teaching and Scientific Research Ministry www.mesrs.dz

The authors are greatful to Dicle University Faculty of pharmacy for opening its laboratory facility.

\section{REFERENCES}

1. Apak, R., Guclu, K., Ozyurek, M., Karademir, S.E. (2004). Novel total antioxidant capacity index for dietary polyphenols and vitamins $\mathrm{C}$ and $\mathrm{E}$, using their cupric ion reducing capability in the presence of neocuproine: CUPRAC Method. J. Agric. Food Chem. 52: 7970-7981.

2. Bachman, D.L., Wolf, P.A., Linn, R.T. (1992). Prevalence of dementia and probable senile dementia of the Alzheimer type in the Framingham study. Neurology. 42: 115-119.

3. Beghalia, M., Ghalem, S., Allali, H., Beloutek, A., Marouf, A. (2008). Inhibition of calcium oxalate monohydrate crystal growth using Algerian medicinal plants, J. Med. Plants Res. 2: 66-70.

4. Bellakhdar, J., Claisse, R., Fleurentain, J., Younos, C. (1991). Repertory of standard herbal drugs in the Moroccan pharmacopoeia. J. Ethnopharmacol. 35: 123-143.

5. Benahmed-Bouhafsoun, A., Djied, S., Mouzaz, F., Kaid-Harche, M. (2013). Phytochemical composition and in vitro antioxidant activity of Chamaerops humilis L. extracts. Int. J. Pharm. Pharm. Sci. 5: 741744.

6. Benmehdi, H., Hasnaoui, O., Benali, O., Salhi, F. (2012). Phytochemical investigation of leaves and fruits extracts of Chamaerops humilis L. J. Mater. Environ. Sci. 3 (2): 320-237.

7. Benmessaoud Left, D., Essaqui, A., Zertoubi, M., Azzi, M., Benaissa, M. (2014). Study of antioxidant activity and anticorrosion action of the methanol extract of dwarf palm leaves (Chamaerops humilis L.) from Morocco. J. Mater. Environ. Sci. 5: 887-898.

8. Bouhafsoun, A., Yilmaz, MA, Boukeloua, A., Temel, 
H., Kaid Harche, M. (2018).Simultaneous quantification of phenolic acids and flavonoids in Chamaerops humilis L. using LC-ESI-MS/MS. Food Sci. Technol (Campinas), 38(1): 242-247 : doi:10.1590/fst.19917.

9. EL-Hilaly, J., Mohamed Hmammouchi, M., Lyoussi, B. (2003). Ethnobotanical studies and economic evaluation of medicinal plants in Taounate province (Northern Morocco). J. Ethnopharmacol., 86:149158

10.Ellman, G.L., Courtney, K.D., Andres, V., Featherstone, R.M. (1964). A new and rapid colorimetric determination of acetyl cholinesterase activity. Biochem. Pharmacol. 7: 88-95.

11.Gaamoussi, F., Israili, Z. H., Âlyousfi, B. (2010). Hypoglycemic and hypolipidemic effects of an aquous extract of Chamaerops humilis leaves in obese, hyperglycemic and hyperlipidemic Meriones shawi rats. Pak. J. Pharm. Sci. 23: 212-219.

12.Gonçalves, S., Medronho, J., Moreira, E., Grosso, C., Andrade, P.B., Valentão, P., Romano, A. (2018). Bioactive properties of Chamaerops humilis L.: antioxidant and enzyme inhibiting activities of extracts from leaves, seeds, pulp and peel. Biotech. 8:88.

13. Hasnaoui, O., Benali, O., Bouazza, M., Benmehdi, H. (2013). Ethnobotanical approaches and phytochemical analysis of Chamaerops humilis L. (Arecaceae) in the area of Tlemcen (western Algeria). Res. J. Pharm. Biol. Chem. Sci. 4: 918.

14.Hirai, Y., Sanada, S., Ida, Y., Shoji, J. (1986). Studies on the Constituents of Palmae.The Constituent of Chamaerops humilis L. and Trachycarpus wagnerianus BECC. Chem. Pharm. Bull. 34: 82-87.

15. Hutzler, P., Fischbach, R., Heller, W., Jungblut, T. P., Reuber, S., Schmitz, R., Veit, M. (1998). Weissenbock, Schnitzler J. P. Tissue localization of phenolic compounds in plants by confocal laser scanning microscopy. J. Exp. Bot. 4: 953-965.

16.Jaen, JC., Gregor, Ve., Lee, C., Davis, R., Emmerling, M. (1996). Acetylcholinesterase inhibition by fused dihydroquinazoline compounds. Bioorg. Med. Chem. Lett. 6: 737-742.

17.Khoudali, S., Benmessaoud Left, D., Essaqui, A., Zertoubi, M., Azzi, M., Benaissa, M. (2014). Study of antioxidant activity and anticorrosion action of the methanol extract of dwarf palm leaves (Chamaerops humilis L.) from Morocco. J. Mater. Environ. Sci. 5 (3): 887-898.

18.Kuppusamy, S., Thavamani, P., Megharaj, M., Lee, Y. B., Naidu, R. (2016). Isolation and characterization of polycyclic aromatic hydrocarbons (PAHs) degrading, $\mathrm{pH}$ tolerant, $\mathrm{N}$-fixing and $\mathrm{P}$-solubilizing novel bacteria from manufactured gas plant (MGP) site soils. Environ. Technol. Innov. 6: 204-219.

19.Mohamed, A. A., Khalil, A. A., EL-Beltagi, H. E. S (2009). Chemical compositions and antioxidant/ antimicrobial activities of kaff maryam (Anastatica hierochuntica) and doum palm (Hyphaene thebaica) cultivated in Egypt. Biyoloji Bilimleri Arastirma Dergisi, 2: 71-79.

20.Moreno, M.I.N., Isla, M.I., Sampietro, A. R., Vattuone, M. A. (2000). Comparison of the free radical scavenging activity of propolis from several regions of Argentina. J. Ethnopharmacol. 71: 109114.

21.Pinho, B. R., Ferreres, F., Valentão, P., Andrade, P. B. (2013). Nature as a source of metabolites with cholinesterase-inhibitory activity: an approach to Alzheimer 's disease treatment. J. Pharm. Pharmacol. 65(12): 1681-1700.

22.Re, R., Pellegrini, N., Proteggente, A., Pannala, A., Yang, M., Rice-Evans, C., (1999). Antioxidant activity applying an improved ABTS radical cation decolorization assay. Free Radic. Biol. Med., 26: 1231-1237.

23.Silva, T., Reis, J., Teixeira, J., Borges, F.,(2014). Alzheimer's disease, enzyme targets and drug discovery struggles: From natural products to drug prototypes. Ageing. Res. Rev. 15: 116-145.

24.Singh, V., Guizani, N., Essa, M. M., Hakkim, F. L. Rahman, M. S. (2012). Comparative analysis of total phenolics, flavonoid content and antioxidant profile of different date varieties (Phœnix dactylifera L.) from Sultanate of Oman. Int. Food Res. J. 19:1063-1070.

25.Slinkard, K., Singleton V. L. (1977). Total phenol analyses: Automation and comparison with manual methods. Am. J. Enology Vitic. 28: 49-55.

26.Williams, C. A., Harborne, J. B. (1973). Negatively charged flavones and tricin as chemosystematic markers in the Palmae. Phytochemistry. 12: 24172430. 